\title{
Gambaran Penderita Infeksi Mata di Rumah Sakit Mata Manado Provinsi Sulawesi Utara Periode Juni 2017 - Juni 2019
}

\author{
Miranda Tehamen, ${ }^{1}$ Laya Rares, ${ }^{2}$ Wenny Supit $^{2}$
}

\author{
${ }^{1}$ Program Studi Pendidikan Dokter Fakultas Kedokteran Universitas Sam Ratulangi Manado \\ ${ }^{2}$ Bagian Ilmu Kesehatan Mata Fakultas Kedokteran Universitas Sam Ratulangi \\ E-mail: mhirandatehamen@gmail.com
}

\begin{abstract}
Eye infections are caused by viruses, bacteria, fungi, or parasites. Infections can be marked with red eyes, painful, watery, and light sensitive. This study was aimed to obtain the profile of eye infections in Rumah Sakit Mata Provinsi Sulawesi Utara (eye hospital) from July 2017 to June 2019. This was a retrospective and descriptive study using data of medical records at Rumah Sakit Mata Provinsi Sulawesi Utara. The results showed that there were 546 eye infection patients, and the most frequent eye infection was conjunctivitis (231 patients $42.31 \%$ ). Female patients were predominant than males $(53.85 \%$ vs $46.15 \%)$. Based on occupation, housewifery was the most frequent occupation related to eye infections (110 patients $\sim 20.15 \%$ ). Based on age, eye infections mostly occured in the category of age 36-45 years (98 patients 17.95\%). Most patients' complaint was red eye (295 patients 54.03\%). Based on location, eye infections mostly occured unilaterally (364 patients $\sim 66.67 \%$ ). In conclusion, eye infection patients were mostly females, at age of 36-45 years, housewifery, had red eye complaint, and located on unilateral side.
\end{abstract}

Keywords: prevalence of eye infections

\begin{abstract}
Abstrak: Infeksi mata adalah penyakit yang terjadi akibat virus, bakteri, jamur atau parasit. Infeksi mata dapat ditandai dengan mata merah, terasa sakit, berair dan peka terhadap cahaya. Penelitian ini bertujuan untuk mengetahui gambaran penderita infeksi mata di Rumah Sakit Mata Provinsi Sulawesi Utara periode Juni 2017-Juni 2019. Jenis penelitian ialah deskriptif retrospektif menggunakan data rekam medik Rumah Sakit Mata Provinsi Sulawesi Utara. Hasil penelitian mendapatkan 546 pasien infeksi mata dan jenis infeksi mata yang terbanyak ialah konjungtivitis yaitu 231 pasien $(42,31 \%)$. Pasien berjenis kelamin perempuan lebih banyak dibandingkan dengan jenis kelamin laki-laki (53,85\% vs 46,15\%). Berdasarkan pekerjaan, didominasi oleh pekerjaan sebagai ibu rumah tangga/IRT (110 pasien 20,15\%). Berdasarkan usia, terbanyak pada kategori usia 36-45 tahun (98 pasien 17,95\%). Berdasarkan keluhan yang dialami pasien didapatkan keluhan terbanyak ialah mata merah (295 pasien 54,03\%) dan berda-sarkan lokasi didapatkan terbanyak pada sisi unilateral mata (364 pasien $\sim 66,67 \%$ ). Simpulan penelitian ini ialah penderita infeksi mata terbanyak pada perempuan, usia 36-45 tahun, didominasi pekerjaan sebagai IRT, dengan keluhan mata merah, dan terdapat pada lokasi sisi unilateral.
\end{abstract}

Kata kunci: prevalensi infeksi mata

\section{PENDAHULUAN}

Mata ialah salah satu panca indera yang sangat penting bagi manusia, namun sering kurang diperhatikan sehingga terkena berbagai macam penyakit. Jika hal ini terjadi maka akan berdampak buruk bagi kehidupan manusia. $^{1}$

Salah satu penyakit mata yang umumnya terjadi yaitu infeksi mata. Infeksi mata adalah penyakit yang terjadi ketika virus, bakteri, jamur atau parasit menginfeksi mata. Infeksi mata dapat ditandai dengan 
mata merah, terasa nyeri, berair, dan peka terhadap cahaya. ${ }^{2}$ Salah satu tanda inflamasi, baik yang terlokalisir pada mata atau yang terjadi secara sistemik yaitu mata merah. Manifestasi mata merah seringkali terdapat pada kasus ringan yang dapat ditatalaksana di pelayanan kesehatan primer, namun beberapa kasus dapat mengancam penglihatan sehingga perlu dirujuk untuk mendapatkan penanganan lanjut. Kasus mata merah yang paling sering ditemukan di praktik sehari-hari yaitu kongjutivitis viral dan alergi, namun kasus lainnya yang lebih berat juga sering didapat. ${ }^{3}$

Tidak semua mata merah disebabkan oleh infeksi. Penyebab mata merah paling sering ialah pelebaran pembuluh darah mata yang disebabkan oleh udara panas, paparan sinar matahari, debu, reaksi alergi, infeksi bakteri atau virus, dan batuk. ${ }^{4}$ Infeksi mata merupakan masalah yang umum muncul di pelayanan kesehatan primer. Konjungtivitis dan keratitis merupakan masalah teratas di antara lima masalah teratas yang paling sering disebut di dua Department of Ophtalmology di Brisbane. $^{5}$

Data Survei Kesehatan Indera tahun 1993-1996 menunjukkan bahwa angka kebutaan di Indonesia mencapai 1,5\% dari seluruh populasi dan yang mengalami kelainan refraksi $(9,5 \%)$, gangguan retina $(8,5 \%)$, kelainan kornea $(8,4 \%)$, dan penyakit lain. ${ }^{6}$ Data Riskesdas tahun 2013 di Provinsi Sulawesi Utara melaporkan kebutaan sebesar $0,8 \%$ dan severe low vision sebesar $0,9 \% .^{7}$ Berdasarkan latar belakang ini, penulis tertarik untuk melakukan penelitian mengenai infeksi mata khususnya mengenai prevalensi infeksi mata di Rumah Sakit Mata Provinsi Sulawesi Utara periode Juni 2017-Juni 2019.

\section{METODE PENELITIAN}

Penelitian ini dilakukan dengan metode deskriptif retrospektif yang menggunakan data di Bagian Rekam Medik Rumah Sakit Mata Provinsi Sulawesi Utara periode Juni 2017-Juni 2019.

Penelitian ini telah mendapat persetujuan dari Komisi Etik Penelitian Kesehatan
RSUP Prof. Dr. R. D. Kandou Manado, dengan nomor keterangan layak etik yaitu No.057/EC/KEPK-KANDOU/X/2019.

\section{HASIL PENELITIAN}

Hasil penelitian menunjukkan bahwa pada periode Juni 2017-Juni 2019, terdapat sebanyak 546 pasien yang didiagnosis infeksi mata di Rumah Sakit Mata Provinsi Sulawesi Utara dengan kejadian terbanyak di periode Juni-Desember 2017 yaitu 257 orang yang menderita blefaritis, konjungtivitis, keratitis, ulkus kornea, uveitis, dan endoftalmitis.

Tabel 1 memperlihatkan bahwa berdasarkan jenis infeksi mata, diperoleh pasien infeksi mata yang terbanyak ialah konjungtivitis berjumlah 231 orang $(42,31 \%)$.

Tabel 1. Prevalensi penderita infeksi mata di Rumah Sakit Mata Provinsi Sulawesi Utara periode Juni 2017-Juni 2019 berdasarkan jenis infeksi mata

\begin{tabular}{ccc}
\hline Infeksi mata & Jumlah & $(\boldsymbol{\%})$ \\
\hline Blefaritis & 78 & 14,29 \\
Konjungtivitis & 231 & 42,31 \\
Keratitis & 172 & 31,5 \\
Ulkus kornea & 47 & 8,6 \\
Uveitis & 2 & 0,37 \\
Endoftalmitis & 16 & 2,93 \\
Total & 546 & 100 \\
\hline
\end{tabular}

Tabel 2 memperlihatkan bahwa berdasarkan kategori usia, diperoleh pasien infeksi mata yang terbanyak ialah kategori usia $36-45$ berjumlah 98 orang $(17,95 \%)$.

Tabel 3 memperlihatkan bahwa berdasarkan jenis kelamin, diperoleh pasien yang berjenis kelamin perempuan 294 orang $(53,85 \%)$ dan yang berjenis kelamin lakilaki berjumlah 252 orang $(46,15 \%)$.

Tabel 4 memperlihatkan bahwa berdasarkan kategori pekerjaan, infeksi mata terbanyak pada pasien yang bekerja sebagai IRT berjumlah 110 orang $(20,15 \%)$.

Tabel 5 memperlihatkan bahwa berdasarkan keluhan utama, diperoleh keluhan pasien infeksi mata yang terbanyak ialah mata merah berjumlah 295 orang $(54,03 \%)$.

Tabel 6 memperlihatkan bahwa berda- 
sarkan lokasi, didapatkan pasien yang mengalami infeksi mata pada sisi unilateral berjumlah 364 orang $(66,67 \%)$ dibanding- kan sisi bilateral berjumlah 182 orang $(33,33 \%)$.

Tabel 2. Prevalensi penderita infeksi mata di Rumah Sakit Mata Provinsi Sulawesi Utara periode Juni 2017-Juni 2019 berdasarkan usia

\begin{tabular}{cccccccc}
\hline $\begin{array}{c}\text { Usia } \\
\text { (tahun) }\end{array}$ & Blefaritis & $\begin{array}{c}\text { Konjungtiviti } \\
\mathbf{s}\end{array}$ & Keratitis & $\begin{array}{c}\text { Ulkus } \\
\text { kornea }\end{array}$ & Uveitis & Endoftalmitis & $\begin{array}{c}\text { Jumlah } \\
(\%)\end{array}$ \\
\hline $0-4$ & $0(0)$ & $12(2,2)$ & $0(0)$ & $0(0)$ & $0(0)$ & $0(0)$ & $12(2,2)$ \\
$5-11$ & $1(0,2)$ & $18(3,3)$ & $4(0,7)$ & $2(0,4)$ & $0(0)$ & $0(0)$ & $25(4,58)$ \\
$12-16$ & $0(0)$ & $8(1,5)$ & $5(0,9)$ & $3(0,55)$ & $0(0)$ & $0(0)$ & $16(2,93)$ \\
$17-25$ & $1(0,2)$ & $27(4,94)$ & $19(3,5)$ & $5(0,91)$ & $0(0)$ & $1(0,18)$ & $55(10,1)$ \\
$26-35$ & $3(0,55)$ & $32(5,86)$ & $37(6,8)$ & $6(1.1)$ & $0(0)$ & $1(0,18)$ & $78(14,29)$ \\
$36-45$ & $3(0,55)$ & $43(7,87)$ & $42(7,7)$ & $8(1,46)$ & $0(0)$ & $2(0,37)$ & $98(17,95)$ \\
$46-55$ & $12(2,2)$ & $35(6,4)$ & $34(6,23)$ & $10(1,8)$ & $1(0.18)$ & $4(0,73)$ & $96(17,58)$ \\
$56-65$ & $25(4,6)$ & $29(5,3)$ & $19(3,5)$ & $6(1,1)$ & $0(0)$ & $4(0,73)$ & $83(15,2)$ \\
$>65$ & $33(6,04)$ & $27(4,94)$ & $12(2,2)$ & $7(1,28)$ & $1(0.18)$ & $4(0,73)$ & $83(15,2)$ \\
Total & $78(14,3)$ & $231(42,31)$ & $172(31,5)$ & $47(8,61)$ & $2(0.37)$ & $16(2,93)$ & $546(100)$ \\
\hline
\end{tabular}

Tabel 3. Prevalensi penderita infeksi mata di Rumah Sakit Mata Provinsi Sulawesi Utara periode Juni 2017-Juni 2019 berdasarkan jenis kelamin

\begin{tabular}{cccccccc}
\hline $\begin{array}{c}\text { Jenis } \\
\text { kelamin }\end{array}$ & Blefaritis & Konjungtivitis & Keratitis & $\begin{array}{c}\text { Ulkus } \\
\text { kornea }\end{array}$ & Uveitis & Endoftalmitis & $\begin{array}{c}\text { Jumlah } \\
(\boldsymbol{\%})\end{array}$ \\
\hline Laki-laki & $24(4,39)$ & $9(17,95)$ & $86(15,75)$ & $33(6,04)$ & $2(0,37)$ & $9(1,65)$ & $252(46,15)$ \\
Perempuan & $54(9,89)$ & $133(24,36)$ & $86(15,75)$ & $14(2,56)$ & $0(0)$ & $7(1,3)$ & $294(53,85)$ \\
Total & $78(14,29)$ & $231(42,31)$ & $172(31,5)$ & $47(8,6)$ & $2(0,37)$ & $16(2,93)$ & $546(100)$ \\
\hline
\end{tabular}

Tabel 4. Prevalensi penderita infeksi mata di Rumah Sakit Mata Provinsi Sulawesi Utara periode Juni 2017-Juni 2019 berdasarkan pekerjaan

\begin{tabular}{cccccccc}
\hline Pekerjaan & Blefaritis & Konjungtivitis & Keratitis & $\begin{array}{c}\text { Ulkus } \\
\text { kornea }\end{array}$ & Uveitis & Endoftalmitis & $\begin{array}{c}\text { Jumlah } \\
(\%)\end{array}$ \\
\hline Buruh & $0(0)$ & $0(0)$ & $2(0,37)$ & $2(0,37)$ & $0(0)$ & $0(0)$ & $4(0,73)$ \\
IRT & $27(4,94)$ & $46(8,4)$ & $27(4,945)$ & $5(0,92)$ & $0(0)$ & $5(0,92)$ & $110(20,15)$ \\
Mahasiswa & $1(0,2)$ & $14(2,56)$ & $7(1,28)$ & $2(0,37)$ & $0(0)$ & $0(0)$ & $24(4,4)$ \\
Pelajar & $0(0)$ & $27(4,95)$ & $14(2,56)$ & $8(1,46)$ & $0(0)$ & $0(0)$ & $49(8,97)$ \\
Swasta & $6(1,1)$ & $28(5,1)$ & $41(7,5)$ & $2(0,37)$ & $0(0)$ & $4(0,73)$ & $81(14,8)$ \\
Pensiunan & $17(3,1)$ & $13(2,38)$ & $4(0,9)$ & $0(0)$ & $0(0)$ & $0(0)$ & $34(6,23)$ \\
Guru/Dosen & $4(0,73)$ & $5(0,92)$ & $5(0,9)$ & $0(0)$ & $0(0)$ & $1(0,18)$ & $15(2,75)$ \\
Dokter/Bidan & $0(0)$ & $0(0)$ & $3(0,55)$ & $0(0)$ & $0(0)$ & $0(0)$ & $3(0,55)$ \\
Pendeta & $0(0)$ & $3(0,55)$ & $2(0,37)$ & $0(0)$ & $0(0)$ & $0(0)$ & $5(0,92)$ \\
Petani & $5(0,92)$ & $11(2)$ & $13(2,38)$ & $14(2,56)$ & $1(0,18)$ & $2(0,37)$ & $46(8,4)$ \\
Nelayan/ & $0(0)$ & $3(0,55)$ & $2(0,37)$ & $1(0,18)$ & $0(0)$ & $1(0,18)$ & $7(1,3)$ \\
Pelaut & $0(0)$ & $2(0,37)$ & $2(0,37)$ & $0(0)$ & $0(0)$ & $0(0)$ & $4(0,7)$ \\
Sopir & $0(0)$ & $3(0,55)$ & $3(0,55)$ & $2(0.37)$ & $0(0)$ & $0(0)$ & $8(1,47)$ \\
Tukang & $5(0,92)$ & $15(2,75)$ & $14(2,56)$ & $0(0)$ & $0(0)$ & $1(0,18)$ & $35(6,4)$ \\
ASN & $0(0)$ & $0(0)$ & $3(0,55)$ & $0(0)$ & $0(0)$ & $1(0,18)$ & $4(0,73)$ \\
TNI/POLRI & $2(0.37)$ & $8(1,47)$ & $9(1,65)$ & $2(0.37)$ & $0(0)$ & $1(0,18)$ & $22(4,03)$ \\
Wiraswasta & $0(0)$ & $4(0,73)$ & $4(0,7)$ & $1(0.18)$ & $0(0)$ & $0(0)$ & $9(1,65)$ \\
Honorer & $0(0)$ & $1(0,18)$ & $0(0)$ & $0(0)$ & $0(0)$ & $0(0)$ & $1(0,2)$ \\
Wartawan & $1(0,2)$ & $18(3,3)$ & $0(0)$ & $0(0)$ & $0(0)$ & $0(0)$ & $19(3,5)$ \\
Dibawah umur & $10(1,8)$ & $30(5,5)$ & $17(3)$ & $8(1,46)$ & $1(0,18)$ & $0(0)$ & $66(12,09)$ \\
Tidak bekerja & $18)$ & $172(31,5)$ & $47(8,6)$ & $2(0,37)$ & $16(2,93)$ & $546(100)$ \\
Total & $78(14,29)$ & $231(42,31)$ & $17)$ & & & &
\end{tabular}


Tabel 5. Prevalensi penderita infeksi mata di Rumah Sakit Mata Provinsi Sulawesi Utara periode Juni 2017-Juni 2019 berdasarkan keluhan utama

\begin{tabular}{cccccccc}
\hline $\begin{array}{c}\text { Keluhan } \\
\text { utama }\end{array}$ & Blefaritis & Konjungtivitis & Keratitis & $\begin{array}{c}\text { Ulkus } \\
\text { kornea }\end{array}$ & Uveitis & Endoftalmitis & $\begin{array}{c}\text { Jumlah } \\
(\%)\end{array}$ \\
\hline Merah & $17(3,1)$ & $123(22,5)$ & $110(20,15)$ & $32(5,86)$ & $1(0,18)$ & $12(2,2)$ & $295(54,03)$ \\
Bengkak & $3(0,55)$ & $13(2,4)$ & $3(0,55)$ & $0(0)$ & $0(0)$ & $1(0,18)$ & $20(3,7)$ \\
Gatal & $10(1,83)$ & $22(4,03)$ & $2(0,37)$ & $0(0)$ & $0(0)$ & $0(0)$ & $34(6,23)$ \\
Sekret & $5(0,92)$ & $8(1,5)$ & $1(0,18)$ & $0(0)$ & $0(0)$ & $0(0)$ & $14(2,6)$ \\
Kabur & $16(2,9)$ & $18(3,3)$ & $25(4,6))$ & $7(1,3)$ & $1(0,18)$ & $1(0,18)$ & $68(12,45)$ \\
Nyeri & $9(1,65)$ & $18(3,3)$ & $12(2,2)$ & $6(1,1)$ & $0(0)$ & $2(0,37)$ & $47(8,61)$ \\
Berpasir & $0(0)$ & $4(0,73)$ & $2(0,37)$ & $0(0)$ & $0(0)$ & $0(0)$ & $6(1,01)$ \\
Sakit kepala & $1(0,18)$ & $5(0,9)$ & $3(0,55)$ & $0(0)$ & $0(0)$ & $0(0,0)$ & $9(1,65)$ \\
Mengganjal & $1(0,18)$ & $5(0,9)$ & $3(0,55)$ & $1(0,18)$ & $0(0)$ & $0(0)$ & $10(1,83)$ \\
Silau & $0(0)$ & $0(0)$ & $4(0,7)$ & $0(0)$ & $0(0)$ & $0(0)$ & $4(0,7)$ \\
Berair & $16(2,93)$ & $15(2,75)$ & $7(1,3)$ & $1(0,18)$ & $0(0)$ & $0(0)$ & $39(7,1)$ \\
\hline
\end{tabular}

Tabel 6. Prevalensi penderita infeksi mata di Rumah Sakit Mata Provinsi Sulawesi Utara periode Juni 2017-Juni 2019 berdasarkan lokasi

\begin{tabular}{cccccccc}
\hline Lokasi & Blefaritis & Konjungtivitis & Keratitis & $\begin{array}{c}\text { Ulkus } \\
\text { kornea }\end{array}$ & Uveitis & Endoftalmitis & $\begin{array}{c}\text { Jumlah } \\
(\%)\end{array}$ \\
\hline Unilateral & $30(5,49)$ & $130(23,81)$ & $143(26,2)$ & $44(8,06)$ & $2(0,37)$ & $15(93,75)$ & $364(66,67)$ \\
Bilateral & $48(8,8)$ & $101(18,5)$ & $29(5,3)$ & $3(0,55)$ & $0(0)$ & $1(6,25)$ & $182(33,33)$ \\
Total & $78(14,29)$ & $231(42,31)$ & $172(31,5)$ & $47(8,6)$ & $2(0,37)$ & $16(2,93)$ & $546(100)$ \\
\hline
\end{tabular}

\section{BAHASAN}

Hasil penelitian menunjukkan bahwa pada periode Juni 2017-Juni 2019, terdapat sebanyak 546 pasien yang terdiagnosis infeksi mata di Rumah Sakit Mata Provinsi Sulawesi Utara dengan kejadian terbanyak di periode Juni-Desember 2017 sebanyak 257 pasien infeksi mata. Berdasarkan jenis infeksi mata, diperoleh pasien yang terbanyak ialah konjungtivitis $(42,31 \%)$. Hasil penelitian ini selaras dengan penelitian yang dilakukan oleh Arbaminch University, Ethiopia dimana didapatkan pasien yang terkena konjungtivitis lebih banyak dibandingkan jenis infeksi mata yang lain. ${ }^{8}$

Berdasarkan kategori usia, diperoleh pasien infeksi mata yang terbanyak ialah kategori usia 36-45 (17,95\%). Hasil ini berbeda dengan penelitian yang dilakukan oleh Department of Microbiology India yang mendapatkan infeksi mata lebih banyak pada usia $>60$ tahun. $^{9}$

Berdasarkan jenis kelamin, diperoleh pasien infeksi mata yang berjenis kelamin perempuan $(53,85 \%)$ lebih banyak daripada yang berjenis kelamin laki-laki $(46,15 \%)$. Hasil ini sejalan dengan penelitian yang dilakukan oleh Institute of Biomedical Sciences Ethiopia yang mendapatkan lebih banyak infeksi mata pada pasien yang berjenis kelamin perempuan dibandingkan yang berjenis kelamin laki-laki. ${ }^{10}$ Perempuan biasanya lebih sering menggunakan lensa kontak untuk mempercantik diri. Penggunaan dan penyimpanan lensa kontak yang tidak tepat dan tidak bersih dapat menjadi tempat berkembang biaknya mikroorganisme yang dapat menyebabkan infeksi pada mata. ${ }^{11}$

Berdasarkan kategori pekerjaan, didapatkan pasien infeksi mata yang terbanyak pada IRT $(20,15 \%)$. Hasil ini berbeda dengan penelitian yang dilakukan oleh Institute of Biomedical Sciences, Ethiopia yang melaporkan lebih banyak infeksi mata pada pasien yang memiliki pekerjaan sebagai petani.

Berdasarkan keluhan utama, diperoleh 
keluhan pasien infeksi mata yang terbanyak ialah mata merah $(54,03 \%)$. Umumnya infeksi mata memunculkan gejala mata merah, namun tidak semua infeksi mata menyebabkan mata merah. Keluhan yang dirasakan oleh pasien bergantung pada penyebab terjadinya infeksi mata. ${ }^{12}$

Berdasarkan lokasi, didapatkan bahwa pasien yang mengalami infeksi mata pada sisi unilateral $(66,67 \%)$ lebih banyak dibandingkan dengan sisi bilateral $(33,33 \%)$. Sampai saat ini peneliti belum mendapatkan penelitian lain mengenai infeksi mata berdasarkan lokasi.

\section{SIMPULAN}

Gambaran penderita infeksi mata di Rumah Sakit Mata Provinsi Sulawesi Utara periode Juni-Desember 2017 yang terbanyak ialah penderita dengan konjungtivitis, jenis kelamin perempuan, usia 36-45 tahun, keluhan mata merah, pekerjaan sebagai IRT, dengan lokasi di unilateral.

Bagi peneliti lanjut disarankan untuk meneliti hubungan infeksi mata dengan lingkungan, httriwayat penyakit, kebiasaan, dan pengobatan. Penderita infeksi mata diharapkan segera memeriksakan mata untuk menekan progresivitas penyakit. Bagi lembaga kesehatan diharapkan dapat memberikan penyuluhan dan edukasi kepada seluruh masyarakat mengenai faktor risiko, tindakan pencegahan, dan pentingnya penggunaan alat pelindung diri (APD) saat melakukan pekerjaan.

\section{Konflik Kepentingan}

Penulis menyatakan tidak terdapat konflik kepentingan dalam studi ini.

\section{DAFTAR PUSTAKA}

1. Reisa R, Jusak, Pantjawati S. Sistem pakar untuk diagnosis penyakit mata. JSIKA. 2013; 2:30-1.

2. National Eye Institute. Eye Infections. 2019. [cited 2019 Sep 2]. Available from: https://medlineplus.gov/ eyeinfections. html
3. Sitorus RA. Masalah mata merah. In: Sitorus RA, Sitompul R, Widyawati S, Banni $\mathrm{AP}$, penyunting. Buku Ajar Oftamologi. Jakarta: BPFKUI, 2018; p. 83439.

4. Save Sight Institute. Common Eye Infection. Australia: NPS MedicineWise. 2018. Available from: https://www.ncbi.nlm. nih.gov/pmc/articles/PMC6003010/

5. Putu GS, Putu W. Buku Panduan Belajar Koas Ilmu Kesehatan Mata. Denpasar: FK Udayana, 2017; p. 2-3.

6. Depkes RI. Gangguan penglihatan masih menjadi masalah kesehatan. 2013. Available from: http://www.depkes. go.id/article/view/845/gangguanpenglihatan-masih-menjadi-masalahkesehatan.html

7. Depkes RI. Situasi gangguan penglihatan dan kebutaan. 2014. Available from: http: //www.kemkes.go.id/download.php?fil e=download/pusdatin/infodatin/infodati n-penglihatan.pdf

8. Akillu A, Bitew A, Dessie W, Hailu E, Asamene N, Mamuye $\mathrm{Y}$, et al. Prevalence and drug susceptibility pattern of bacterial patho-gens from ocular infection in St. Paul's Hospital Millenium Medical College, Ethiopia. J Bacterial Mycol. 2018; 5(8):1085.

9. Umamageswari SSM, Jeya M, Suja C. Study of bacterial and fungal profile of external ocular infections in a tertiary care hospital. NJLM. 2013;2(3):6-10.

10. Mabrahtu T, Muthupandian S, Araya G, Dawit G. Ocular bacterial infections at Quiha Ophtalmic Hospital, Nothern Ethiopia: an evaluation according to the risk factors and the antimicrobial susceptibility of bacterial isolates. BMC Infect Dis. 2017; 17:207.

11. Szczotka-Flynn LB, Pearlman E, Ghannoum M. Microbial contamination of contact lenses, lens care solutions, and their accessories: a literature review. Eye Contact Lens. 2010;36(2):116-29.

12. Shimon R. Overview of common and less common ocular infections. Advances in Common Eye Infections (6th ed). 2016. p. 4-5. Available from: http//dx.doi.org/ 10.5772/65957. 